FIU Law Review

Volume 1

Number 1 Inaugural Issue

Article 10

Spring 2006

\title{
The Logic of Rights vs. The Logic of Representation: The Case of Cohabitation in Spain
}

Blanca Rodriguez Ruiz

University of Seville, Spain

Follow this and additional works at: https://ecollections.law.fiu.edu/lawreview

Part of the Other Law Commons

Online ISSN: 2643-7759

\section{Recommended Citation}

Blanca R. Ruiz, The Logic of Rights vs. The Logic of Representation: The Case of Cohabitation in Spain, 1 FIU L. Rev. 89 (2006).

DOI: https://dx.doi.org/10.25148/lawrev.1.1.10

This Symposium is brought to you for free and open access by eCollections. It has been accepted for inclusion in FIU Law Review by an authorized editor of eCollections. For more information, please contact lisdavis@fiu.edu. 


\title{
The Logic of Rights vs. The Logic of Representation: The Case of Cohabitation in Spain
}

\author{
Blanca Rodríguez Ruiz ${ }^{\dagger \dagger}$
}

\section{PEOPLE's RePresentatives Vs. COURTS: AN INTRODUCTION}

Continental Europe has a history of mistrust of courts. As Europe is well aware, the surge of a new political system never brings along with it a fresh civil society. As a result, forces within civil society inherited from the old regime are bound to have some presence in the new political order. To a significant degree, courts often embody these old forces and act as a means through which they are introduced. They are thus regarded as a branch of power that enables the importation of vestiges of the old social order into the new one. This thought dominated continental European democracies after the Second World War and was also present in the democratic system that came about in Spain in 1978 after nearly forty years of dictatorship. Moreover, this thought has dominated continental Europe more broadly through its turbulent democratic history beyond these historical events. From the beginning, European democracies reacted against the judiciary as a branch of power that served to incorporate the Ancien Regime into the new order and strove to limit courts to being, in Montesquieu's famous words, merely "the mouth that pronounces the words of the law."1 The new democracies in continental Europe aimed to empower Parliament in order to let the people's voice take the lead of political events through people's representatives. Consistent with this way of thinking, during the XIX century European Constitutions only set limits to Parliament at the political level, not the legal one. Constitutions were documents with the

\footnotetext{
$\dagger \quad$ A shorter version of this paper was presented at the Conference "Rethinking 'Legal Transplants' and 'Mixed Jurisdictions': When Civilian Legal Reasoning Meets Constitutional Thought”, held in Paris in July 2005 and organised by the University of Cornell. I would like to thank all participants in the Conference for their comments and insights, very specially Annalise Riles and Mitchel Lasser for putting together a most stimulating event.

i† University of Seville, Spain.

1 Charles de Secondat Montesquieu, The Spirit of The Laws 159 (Thomas Nugent trans., Univ. Cal. Press 1949) (1748).
} 
same force as any Parliamentary law and could consequently be amended by one such law, as embodying the will of Parliament. Parliament was the people's ally, not their potential enemy. Their enemies were embodied in the King and in other still remaining aristocratic sources of power, on the one hand, and, on the other, in the judiciary, to the extent that courts channelled old-regime values and ways of thinking into the new democracies. The realisation that representatives were imperfect and that their actions could actually turn against people's interests came to inform democratic thought only later. Indeed, it constituted a more developed stage within the history and ways of thinking of continental Europe. Originally, threats to people's interests were not found in Parliament, so that having rights against it was an unfamiliar political battle. Threats were found rather in the remains of the Ancien Regime present in civil society and in political power, of which the judiciary exemplified both. Hence, enjoying fundamental rights against Parliament to be made effective by courts was a concern well-removed from the political efforts of the best part of the XIX century.

This was not the case in the United States. Here, Congress was indeed regarded as the people's ally, but as a dangerous one, an ally whose role it was to enact the will of people, but one always ready to have the tyranny of the majority imposed over minorities and have minorities oppressed as a result. People's representatives undoubtedly had a very relevant role to play in the constitutional system of the United States, but their decisions could not be trusted to the extent of going unchecked. The Constitution stood as a norm superior to laws enacted by Congress and setting limits to them, these limits including a list of constitutional or, in the continental European terminology, fundamental rights. Constitutional or fundamental rights were devised as a means to make sure that the majority did not overstep certain lines, lines that were drawn for the purpose of protecting minorities against majority decisions. From early on, the role of protecting rights fell on the judicial branch, led by the Supreme Court, in a system where courts were not subject to the same lack of trust as their continental European counterparts.

As mentioned above, mistrust of courts was revived after fascist experiences throughout Europe, but so was an enhancement of the importance of individual rights, conceived as constitutional rights in the style of the United States, that is, as provisions included in a Constitution with a force superior to that of all other norms. Rights became the informants of the whole legal system and placed themselves above all public power, including the legislature. This means that, in the area of constitutional or, in Europe, fundamental rights, some branch of power had to be in a position to impose its decisions even over the legislature's will. Since mistrust of 
courts disqualified the judicial branch for this task, a special tribunal, the Constitutional Court, was created to deal with infringements upon fundamental rights by all branches of public power, including the legislature.

There then started to take form, both legally and socially, a culture of right superseded to, and in a good measure in tension with, the culture of having people's interests protected through representation. To be sure, an important role was reserved to people's representatives in the definition of rights. The best example is the reserve of law in the development of fundamental rights that to some extent prevails in European systems. Yet an undeniable tension arose between the logic of fundamental rights and the logic of representation. Indeed, if rights are to be fundamental, elements of a constitution conceived as a norm superior to all other norms, including norms enacted by Parliament, then they must apply directly regardless of any legislative action. They must apply directly also against any legislative action that contradicts them. Introducing the logic of fundamental rights in European systems, which is but the logic of the supreme normative force of constitutions, thus poses a direct challenge to European civil-law systems and their traditional ways of thinking in terms of representation.

In Spain, the tension referred to above has been made explicit in some instances of incompatibility between the system of protection of rights framed in the Constitution of $1978,{ }^{2}$ and the one foreseen in the European Convention on Human Rights. ${ }^{3}$ All while keeping in tune with the European tradition, the Spanish Constitution has largely assumed the logic of rights. Thus, Article 53 establishes that only Parliamentary laws can develop fundamental rights, so that rights in need of normative development (the right to receive an education springs to mind) need the collaboration of Parliament to come into full force. ${ }^{4}$ Yet Article 53 does not require that there must be a law behind any limitation imposed upon a fundamental right. What is required by the Spanish Constitution, as made clear by the Constitutional Court on many occasions, and as pertains to the logic of rights, is on the other hand that every restriction of fundamental rights be endorsed by a substantiated judicial decision. This requirement is implicit in the recognition of every fundamental right and explicitly provided for some, as is the case of the right to the secrecy of telecommunications recognised in Article 18.3 of the Constitution. ${ }^{5}$ In accordance with this logic

\footnotetext{
2 CONSTITUCión [C.E.] [Constitution] (Spain), translated in 18 CONSTITUTIONS OF THE WoRLD 5 (Gilbert H. Flanz, ed., Oceana Publications 2004) [herinafter ConstituTIONS OF THE WORLD].

3 Council on Europe, European Convention on Human Rights, May 6, 1963, E.T.S. No. 5 [hereinafter ECHR].

4 CONSTITUTIONS OF THE WORLD, supra note 2, at art. 53.

$5 \quad$ Id. at art. 18.3.
} 
of rights, the Spanish Constitutional Court never required that there be a law behind the limitation of a right, least of all the right to the secrecy of telecommunications of Article 18.3, while being very strict on the requirement that every restriction must be based on a judicial decision and that this decision be sufficiently substantiated.

As a supranational document, on the other hand, the European Convention on Human Rights is heavily influenced by the logic of representation and has a significant degree of deference to the will of national parliaments. As a result, it requires that any limitation of the rights recognised in it be based on a law. This applies to the right to the secrecy of telecommunications recognised in Article 8. ${ }^{6}$ In order to account for all systems within the Council of Europe, the European Court of Human Rights has given the term "law" a broad meaning, so that "law" can be any kind of norm, including well-settled judicial norms, that clearly authorises the limitation. This is in any case a different vision of rights from the one assumed by the Spanish Constitution. Their difference was decisive in the solution of the case Valenzuela v. Spain, decided by the European Court of Human Rights on July 30, 1998. ${ }^{7}$ Here, the Spanish Constitutional Court had declared inadmissible a case concerning the violation of the secrecy of telecommunications on the basis that, in this case, interference with telecommunications had been backed by a sufficiently justified judicial decision, paying no heed to the fact, as irrelevant in our constitutional system, that beyond the Constitution itself and its general terms, there was no norm, Parliamentary or of any kind, authorising the interference. ${ }^{8}$ This state of affairs did not satisfy the European Court of Human Rights, who found a violation of Article 8 of the Convention in the lacking of such a clear norm. ${ }^{9}$ As a result, the Spanish Constitutional Court found itself having to accept, though indeed grudgingly, a decision going against the logic of rights that prevails in the Spanish Constitution.

\section{ECHR, supra note 3, at art. 8.}

Valenzuela v. Spain, App. No. 27671/95, 28 Eur. H.R. Rep. 483 (1999).

Id.

9 Id.; see also Blanca Rodriguez Ruiz, El caso Valenzuela Contreras y nuestro sistema de Derechos Fundamentales [The Case of Valenzuela Contreras and Our System of Fundamental Rights], 56 REVISTA ESPAÑola DE DERECHO CONSTITUCIONAL 223, (1999) [hereinafter Our System of Fundamental Rights].

10 Sentencias del Trubunal Constitucional Sistematizadas y Comentadas [S.T.C.] [Constitutional Court] April 5, 1999 (R.J., 49/1999); See Blanca Rodriguez Ruiz El coste de los Derechos Fundamentales. Un comentario de la STC 49/1999, de 5 de abril, 3 TEORÍA Y REALIDAD CONSTITUCIONAL 315 (1999). S.T.C. ('Sentencia del Tribunal Constitucional') is a Final Decision of the Constitutional Court; A.T.C. ('Auto del Tribunal Constitucional') is a Decision of Admissibility of the Constitutional Court; F.J. ('Fundamento Jurídico') is a Legal Ground for the Court's decision; finally, S.T.S. ('Sentencia del Tribunal Supremo') is a Final Decision of the Supreme Court. 
Beyond this conflict between the Spanish Constitution and the European Convention on Human Rights as exemplified in the case Valenzuela $v$. Spain, a similar conflict of logic can be perceived within the Spanish system in the way it is responding to the needs of protection experienced by cohabiting couples. The need of offering cohabitants adequate protection has been strongly felt for the last decade. As we shall see, the Constitutional Court started to take that need seriously at the end of 1992, while the Supreme Court did so earlier. Meanwhile, in 1998, Catalonia enacted the first law to regulate cohabiting couples and their rights in Spain. ${ }^{11}$ Since then, as a reaction against the inactivity of the legislature in this field at the national level, eleven of the seventeen Autonomous Communities that make up Spain have enacted laws on cohabitation, and have done so in the span of time between 1998 and 2003, when the laws of the Canary Islands, Extremadura and the Basque Country were enacted. ${ }^{12}$

Two branches of public power, the legislative and the judiciary, have thus sought to grant cohabitants rights in the Spanish legal system, the latter branch encompassing, for our purposes, the Constitutional Court, although, strictly speaking, this Court is not part of the judiciary. They have done so differently, as pertains to their different role within the state. Courts have resorted to general principles and to the rights they contain, ultimately to fundamental rights; the Constitutional Court has particularly resorted to these rights. In order to do so, courts have scrutinised the situation brought before them and have analysed the logic that rules it, in order then to apply to that situation the norm that best captures that logic; this mode of proceeding has been referred to as "principled pragmatism". ${ }^{13}$ It is the only way of proceeding open to courts when they want to regulate a situation for which there is no specific legislation, but also legislators can subscribe to principled pragmatism. They can do so once new legislation is passed in relevant fields. Indeed, in areas such as tenancy, pensions, taxes or adoption rights, the lawmaker can decide whether cohabitants enjoy a given right by looking into the rationale controlling the field in question.

Alternatively, however, laws can come to create a new legal category of cohabitants and assign to them certain formally pre-established rights. It is what the laws on cohabitation enacted in eleven Spanish Autonomous Communities have come to do. In these eleven Communities, unmarried

11 Law 10/1998, 15 July.

12 Law 6/1999, 26 March (Aragón); Foral Law 26/2000, 3 July (Navarra); Law 1/2001, 6 April (Valencia); Law 18/2001, 19 December (Baleares); Law 11/2001, 19 December (Madrid); Law 4/2002, 23 May (Asturias); Law 5/2002, 16 December (Andalucía); Law 5/2003, 6 March (Canary Islands); Law 5/2003, 20 March (Extremadura); Law 2/2003, 7 March (Basque Country).

13 JefFrey WeEks et AL., SAME SeX Intimacies: FAMilies of Choice AND Other LiFE EXPERIMENTS 127, 191 (Routledge 2001). 
cohabiting couples have the rights granted them by the law in question, provided that they comply with the requirements imposed by that law. These requirements typically are that the partners have lived together for a minimum period of time, one or two years, simply that they live together if they have a child in common, or that they express their will to be cohabitants in a public document. Most Communities require, however, that cohabitants register in a public registry created for this purpose. In order for these laws to apply, partners cannot be minors, relatives up to a certain degree of closeness, be married or be in another cohabiting relationship. People who live together but do not comply with the mentioned requirements find themselves outside the scope of the law enacted in that Community and the rights and benefits it provides, as well as the duties it imposes. This raises some questions. We have, to begin with, the situation of people who cohabit, but find themselves beyond the scope of the relevant law because they do not comply with the requirements it imposes. We also have the issue of whether cohabitants in those Communities enjoy rights not contemplated in the relevant law, but recognised by courts. A further issue concerns those laws on cohabitation that merely require that unmarried partners live together for a given length of time in order to apply to them, indeed in order to apply to them whether they like it or not. For the law in question would apply to those partners even in cases in which they have made the conscious decision to stay out of both marriage and legally regulated cohabitation and the rights and duties they imply.

The regulation of a legal category of cohabitants by the lawmaker is regarded in Spain as the most reasonable way of proceeding. It is thought to be the lawmaker's job to address this social phenomenon and regulate it in a comprehensive way. The reluctance to comply with this task manifested by the conservative central government in power in Spain between 1996 and 2004 encouraged Autonomous Communities to take the lead in the matter. By doing so, they came to supersede the logic of representation to the logic of rights that had been developed by the Supreme and the Constitutional Courts. Ultimately, tensions can arise in the solution to specific cases resulting from these two different logics. Let us now have a look, first, at the logic of rights as developed by the Spanish Constitutional Court, and, second, at how the same logic has been applied by the Spanish Supreme Court. We will turn, third, to see the way the logic of representation has come to supersede the logic of rights.

\section{THE LOGIC OF RIGHTS AND THE SPANISH CONSTITUTIONAL COURT ON COHABITATION}

When the Spanish Constitutional Court was first confronted with the rights of cohabitants, it had to interpret them from the perspective of four 
constitutional provisions. There is, above all, Article 14 according to which, "Spaniards are equal before the law, without any discrimination for reasons of birth, race, sex, religion, opinion or any other personal or social condition or circumstance." 14

Article 14 should be read in conjunction with Article 9.2:

It is the responsibility of the public powers to promote conditions so that liberty and equality of the individual and the groups he or she joins will be real and effective; to remove those obstacles which impede or make difficult their full implementation, and to facilitate participation of all citizens in the political, economic, cultural and social life. $^{15}$

Article 32 then stipulates the application of the Article 14 clause on equality in the context of marriage:

1. Man and woman have the right to contract matrimony with full juridical equality.

2. The law shall regulate the forms of matrimony, the age and capacity for contracting it, the rights and duties of the spouses, causes for separation and dissolution and their effects. ${ }^{16}$

Finally, there is also Article 39:

1. The public authorities shall assure the social, economic, and juridical protection of the family.

2. The public authorities shall assure the complete protection of children, who are equal before the law regardless of their parentage and regardless of the marital status of their mothers. The law shall make it possible to investigate paternity.

3. Parents must provide their children, born in or out of wedlock, with assistance of every kind during the time they are minors and in other cases where it is legally proper.

4. Children shall enjoy the protection provided in international agreements which safeguard their rights. ${ }^{17}$

The first question to be answered is whether Articles 32 and 39 are to be read independently, that is, whether the constitutional duty of public power to protect the family is independent from marriage. Their independ

4 COnstitutions OF THE WORLD, supra note 2, at art. 14.

15 Id. at art. 9.2

16 Id. at art. 32.

17 Id. at art. 39. 
ence is indeed suggested by their being the object of attention of two different articles belonging, moreover, to different parts of the Constitution. ${ }^{18} \mathrm{~A}$ reading of them as independent provisions seems reinforced by the history of Article 32. Indeed, previous drafts of Article 32 linked the right to marry to the creation of family relations, ${ }^{19}$ as is the case of most European Constitutions. $^{20}$ Yet, in what appears to have been a conscious decision of our constitutional framers to separate the notion of family from the marriage institution, every mention of the family disappeared from the final text of Article 32. The separation of both provisions is the reading embraced, after some initial reluctance, by the Constitutional Court. ${ }^{21}$ Admitting, however, that the family deserves constitutional protection even where it is not based on marriage is not the end of the story. Rather, it brings forth the need to define what the family is beyond marriage, where it deserves protection and how much protection it deserves in constitutional terms. In particular, it must be determined when a difference in treatment between married couples and other forms of family is justified under the Spanish Constitution and why.

For longer than ten years the Constitutional Court managed to avoid these questions, basically because it did not at heart embrace the independence of marriage and the family protected by the Constitution. Only at the end of 1992 did it confront the issue with full force and in a radical twist established, first of all, that a family is a framework of dependence and solidarity that usually (but it seems, not necessarily) entails cohabitation. ${ }^{22}$ Second, the Constitutional Court found that different treatment between families based on marriage and other forms of family could be justified on the basis of Article 32, mostly in as far as the preservation of marriage as an

18 Thus, whereas Article 32 is included in Section 2 Chapter 2 of Title I, Article 39 belongs to Chapter 3 of Title I.

19 José Luis Serrano, La familia como asunto de estado, el matrimonio como derecho del ciudadano [Family as a Concern of the State, and Marriage as a Right of the Citizen], 4 REVISTA DE LA FACUlTAD DE DERECHO DE LA UNIVERSIDAD DE GRANADA 45, 49 (2001) [hereinafter Marriage as a Right].

20 Exceptions are to be found in the Constitutions of the Scandinavian countries and Denmark. Some Constitutions even mention the importance of protecting the family based on marriage as the basic social institution. IR. CONST. art. 41 (Ireland); COSTITUZIONE [COST.] [CONSTITUTION], art. 29 (Italy); GrEeCE Const., art. 21 (Greece). See also Universal Declaration of Human Rights, Dec. 10, 1948, art. 16; International Covenant of Civil and Political Rights, Dec. 16, 1966, art. 23; International Covenant of Economic, Social and Cultural Rights, Dec. 16, 1966, art. 10.1. A similar provision can be found in Article 43.1 of the Spanish Constitution of 1931.

21 Blanca Rodríguez Ruiz, Recognising the rights of unmarried cohabitants in Spain: Why not treat them like married couples?, 2 I-CON 4, 669 (2004).

22 In the words of the Constitutional Court, "La familia es siempre un marco de solidaridades y de dependencias" [The family is a paradigm of solidarity and dependence]. S.T.C. 11 Dec. 1992 (F.J. 4 222/1992). 
institution is concerned. Indeed, Article 32 implies the need to preserve the institution of marriage as a precondition to exercise the right to marry. Giving it certain advantages is therefore justified. These advantages are justified to begin with where marriage as an institution is at stake. Any advantage that goes beyond what the marriage institution requires needs to be the object of specific justification. ${ }^{23}$ This is so, moreover, since Article 32 does not only protect the right to marry; it also protects by implication the right not to marry. If we enjoy the right to enter the marriage institution freely, we must enjoy the right to stay out of it if we so wish without suffering any unjustified legal disadvantages. Obviously justified are those disadvantages implicit in our decision not to enter marriage, disadvantages, that is, that correspond to rights attached to the marriage institution. All other disadvantages have to be justified in order not to set undue limits on the right to stay out of marriage. In brief, only differences in treatment that are duly justified, primarily as being inherent in the logic of marriage as an institution, are allowed under the Constitution. Any advantages enjoyed by married couples over other forms of family that are not sufficiently justified are unconstitutional. Should they ultimately relate to some circumstance alien to the marriage institution, notably to cohabitation, they must be recognised in equal terms to all families where the determining circumstance is present.

We can now ask what these differences inherent to marriage might be or what might be the justification of other differences that prevent different treatment from turning discriminatory. What distinguishes marriage from other forms of family is that in marriage there is an initial formal commitment to solidarity and to bear with one's spouse's dependence, be this physical, financial or emotional, a commitment expressed in front of some public authority. Characteristic of marriage is also the circumstance that this commitment can only be dissolved by the judiciary and that, where it exists, it gives rise to a series of rights, such as inheritance, pensions, family relations or the possibility of joined property if consented by the parties. We may ask now, however, to what extent do these rights relate, strictly speaking, to marriage and not to the existence of such a commitment as mentioned above, to what extent does the recognition of these rights not find the same justification in other forms of expression of the same commitment, such as when this is implicit in certain facts, whether performed at the beginning or during the course of a cohabiting relationship, or even in the mere passage of time in cohabitation, as in common-law marriage. It might even be present in some cases where there is no cohabitation involved. We may ask, in brief, to what extent these rights are justified by 
marriage itself or on different grounds and how far these grounds permit us to grant preferential treatment to marriage.

In the end, by looking into the rationale of differential treatment what we have is the legal significance of marriage diminished in favour of the importance of the family as defined by the Constitutional Court, as a framework of dependence and solidarity, a definition that brings forth the importance of the family as a sociological fact. We have the importance of the marriage institution minimised in favour of the logic of principled pragmatism as controlled by fundamental rights. This means the ultimate victory of reality over fictions, embodied in an important way in the triumph of the logic of rights over fixed rules determined by the logic of representation.

The question of the extent to which marriage can be the object of preferential treatment has not been addressed by the Constitutional Court in general terms. The Constitutional Court has rather confronted each case in order to ascertain whether in that case the difference in treatment was or was not justified. It has thus concluded that the right to succeed one's partner in a tenancy contract, a right initially recognised only to married partners, has nothing to do with marriage itself and has everything to do with the preceding cohabitation of the partners in the premises involved. ${ }^{24}$ Accordingly, it ruled that that right should be extended to cohabiting couples. On the other hand, the Court has been wary of burdening the state with extra costs and has upheld different treatment between married couples and unmarried cohabitants in the field of survival pensions. The fact that in Spain these pensions are called widowhood pensions has been found an indication that they conceptually relate to marriage..$^{25}$ Only in cases where partners could not get married because at least one of them was married to someone else, at a time when divorce was not permitted, were survival pensions granted, provided that divorce had been sought immediately after becoming legally possible. In the same spirit, though avoiding as far as possible to deal with the matter straightforwardly, the Constitutional Court has upheld the different treatment of married and unmarried couples with children contained in income-tax laws, a difference in treatment this time more favourable to unmarried couples. ${ }^{26}$

The result of the case law of the Constitutional Court on the matter of cohabitants' rights is an equation of their rights with those of married couples that is carried out piecemeal on the basis of principled pragmatism, is

24 S.T.C. 212/1992 (F.J. 5). In 1994 a new Act on House Rental came to recognise the same tenancy rights to married and unmarried cohabiting partners.

25 S.T.C. 66/1994, April 25, 1994; ATC 222/1994, July, 11, 1994.

26 S.T.C. 41/2001, Feb. 15, 2001.; S.T.C. 212/2001, Oct. 9, 2001; S.T.C. 21/2002, Jan. 28, 2002. 
at times slow and is often the result of surmounting some previous reluctance on the matter. There was, as we have seen, initial reluctance to separate Articles 32 and 39 of the Constitution. More recently, the Constitutional Court has come to qualify its previous position that ideological freedom is not a legitimate constitutional ground to stay out of marriage without legal consequences. Thus, the Court has made some limited concessions to the right to remain unmarried in connection with ideological freedom and has ruled that marriage must be considered impossible, and therefore dispensed with, if getting married would have violated the ideological freedom of at least one of the partners. The case at issue involved the claimant's right to receive compensatory payment for her partner's political imprisonment during Franco's regime in the same terms as widows. In this case, getting married would have violated the anarchist ideology of the claimant's partner, not because he rejected marriage in general, but because he rejected canonical marriage, the rule during Franco's regime. At that time, civil marriage required a declaration made originally by one partner, since 1958 by both partners, that they were not Catholic, which eventually implied their declaration of apostasy. The Constitutional Court found that such a declaration would go against the right to ideological freedom recognised in Article 16 of the present Constitution. For those opposed to canonical marriage, the only way to preserve their ideological freedom was to stay out of marriage altogether. The Court concluded by equating cohabitation with marriage under the circumstances. ${ }^{27}$

The equation of cohabitation with marriage on the basis of principled pragmatism has therefore been slower and more reluctant in some cases than it might have been, but it seems a well-established trend. We can attribute slowness and reluctance to the prominent role continental Europe reserves for legislators and the tightrope on which Constitutional Courts have to move in civil-law systems in order to earn legitimacy. Constitutional Courts must protect fundamental rights, but they can act merely as negative legislators whose only role is to determine which parts of laws enacted by Parliament contradict the Constitution. They, on the other hand, cannot trespass the line that would turn them into positive lawmakers, a role reserved to people's directly-elected representatives. Yet the line between positive and negative lawmaking activity is not always easy to draw. A decision of the Constitutional Court might be formally negative and yet positively affect legislation. All while protecting fundamental rights, the Spanish Constitutional Court is wary of passing decisions that would have far-reaching effects on the legal system. Making such decisions is regarded

27 S.T.C. 180/2001, Sept. 17, 2001. 
as the proper domain of the lawmaker. This is doubtless the case when it comes to putting financial constraints on public power, as would result from equating cohabitants and married couples in the fields of pensions or the income tax. On the other hand, principled pragmatism has presided the Constitutional Court's granting of rights to cohabitants in the field of tenancy contracts. More importantly, the Constitutional Court has availed us of a definition of the family as independent from marriage and of a criterion to grant rights to different forms of family, that are well entrenched in principled pragmatism and have potential to go far beyond tenancy and the rights connected therewith. Indeed, they have potential to diminish the importance of law as fiction and bring about an approximation of law to social reality.

\section{ThE SPANISH SUPREME COURT AND PRINCIPLED PRAGMATISM}

Also, the Spanish Supreme Court has made use of principled pragmatism in order to grant rights to unmarried cohabitants. To this end it has not given a working definition of the family. Nor has it established when a nonmatrimonial family deserves protection and how much protection. It is not the role of the Supreme Court to say how the Constitution should be interpreted. The Constitutional Court is in charge of that. The Supreme Court has simply looked into the rationale controlling relations and has applied a befitting legal framework to the case at hand. The Supreme Court has made use mainly of two notions, the notion of unjust enrichment and the notion of irregular commercial society. On the basis of these two notions it has proceeded to grant rights to economic compensation to an abandoned partner. It has granted rights to an abandoned partner, first, when she (for it is usually the female partner in a heterosexual relationship who is in this position) had fully or partly relinquished her earning possibilities for the sake of homemaking and had in that way helped her male partner to do paid work while at the same time having his home and his family looked after. The Supreme Court has considered that in those cases the unpaid work carried out by the female partner has benefited the male partner to the extent of allowing him to engross his riches at her expense, at the expense of her abandoning her possibilities to do likewise. Hence, the Supreme Court has applied to these cases the notion of unjust enrichment. ${ }^{28}$ In addition to this, an irregular commercial society has been found to exist where the female partner, though without any formal business relationship with her male partner, had helped him to set up or run his business, to the extent that in

28 See STS, Dec. 11, 1992 (R.J., No. 9733, p. 12743). 
the eyes of the law, the Supreme Court said, they should both be regarded as informal business partners. ${ }^{29}$

This is as far as the Supreme Court has found itself able to apply principled pragmatism in our legal system. It has not, for instance, been in a position to apply the joined-property financial regime of marriage to unmarried couples. ${ }^{30}$ Doing so would require a change in the legal framework, something the Supreme Court is not entitled to do. Only the Constitutional Court can question the constitutionality of Parliamentary laws, or indeed of any norm having the force of law, in the Spanish system. Yet within the boundaries of its role, the Supreme Court's application of principled pragmatism has been consistent and determined, indeed more consistent and determined than has been the faithfulness to principled pragmatism shown by the Constitutional Court. To be fair, the Supreme Court does not stand face to face with the lawmaker and the democratic legitimacy that supports it. Nor does it need to prove its own legitimacy with every decision it makes, as a power alien to the traditional three-pronged separation of power. The Supreme Court is embedded within the judiciary as the highest court of the land and benefits from the legitimacy entailed in the activities of all judicial courts. The Supreme Court has thus always been concerned with imparting justice in the case brought before it, without any further considerations concerning its own legitimacy or the proper distribution of power among the different branches of power. The Supreme Court works within a given legal framework established primarily by the lawmaker. This framework includes legal rules and legal principles and is certainly headed by the Constitution and fundamental rights, but the Supreme Court can only apply it in as far as the lawmaker has provided. Indeed it cannot apply it against the provisions of the lawmaker.

The Supreme Court, in a word, acts from within the logic of civil-law systems, a logic where the will of the lawmaker is not put into question. Facing the lawmaker's inactivity, it simply applies the general principles of the system to the cases before it. It pertains not to the Supreme Court, but to the Constitutional Court to impose the Constitution onto the lawmaker, thus challenging her traditional role in our civil-law system.

\section{LAWS ON COHABITATION}

The lawmaker has not wanted to miss the lead on cohabitation matters. As was mentioned above, eleven of Spain's seventeen Autonomous Communities have enacted laws on cohabitation in light of the inactivity of the

29 See STS, May 18, 1992 (R.J., No. 4907, p. 6449).

30 See STS, Oct. 21, 1992 (R.J., No. 8589, p. 11287). 
central Parliament on the subject. These laws respond to the purpose of simplifying the legal framework of cohabitation, thereby simplifying also courts' endeavours to grant cohabitants rights that befit their situation. They have done so in a very civil-law-like manner, aiming to offer a potentially complete regulation of the situation of cohabitants, in matters, that is, that can be regulated by Autonomous Communities. The first thing to be noted is that, with two exceptions, ${ }^{31}$ these laws only regulate the situation of couples who live as if married; the situation, that is, of cohabitants united by para-conjugal love. With the exception of the regulation offered by the two laws referred to above, all other living circumstances remain unregulated. Recognising any respective rights remains a question for courts to settle, to be decided from within the logic of principled pragmatism, eventually with reference to fundamental rights. Also note that these laws apply explicitly or implicitly to both different-sex and same-sex couples. Indeed, these laws came to a great extent to make up for the lack of a legal right of same-sex couples to marry. Such a right has been recently recognised by central Parliament; ${ }^{32}$ indeed, according to the Constitution, it can only be recognised by central Parliament, not by the Parliaments of Autonomous Communities.

Laws have thus mostly concentrated on the rights of cohabiting couples. As has been mentioned, it is indeed the case that according to Article 149.1.8 of the Spanish Constitution, the regulation of marriage is a matter under the jurisdiction of the central state, not Autonomous Communities. ${ }^{33}$ This Article divides Autonomous Communities for our purposes into two groups: those that traditionally have their own civil regulations (foral law) and those without any such regulations. According to Article $149.1 .8^{\circ}$ of the Spanish Constitution, the former group of Autonomous Communities may go further in the regulation of civil matters. ${ }^{34}$ They may in particular go as far as necessary to preserve, modify or even develop their foral law. ${ }^{35}$ All other Autonomous Communities may not regulate civil matters. That makes their scope of action in the regulation of cohabitation rather limited. This is the case of Andalucía, Asturias, Canarias, Extremadura, Madrid and Valencia. ${ }^{36}$ As a result, laws on cohabitation in these Communities are

31 Law 19/1998, 28 Dec (the Catalan law on cohabitation situations oriented towards mutual assistance); and Foral Law 34/2002, 10 Dec. (the law in force in Navarra on family fostering of senior citizens).

32 Law 13/2005, 1 July.

33 CONSTITUTIONS OF THE WORLD, supra note 2, at art. 149.1.8.

34 Id.

35 Id.

36 It is, however, a contended matter whether Valencia has foral law and what the scope of this law would be. 
rather brief. They mostly regulate the requirements for cohabitation as a couple under the law and the circumstances of the dissolution of that couple. They also foresee the possibility for cohabiting couples to write their financial agreements in a public document and grant partners rights and duties in their relations with the public administration of the Autonomous Community in question as if they were married.

Autonomous Communities with their own foral law offer, on the other hand, a more thorough regulation of cohabitation. This is the case of Aragón, Baleares, Catalonia, Navarra and the Basque Country. They regulate the financial effects of cohabitation, its effects on common children and the consequences of its dissolution by one party's will or death, especially inheritance. In addition to this, all these Communities but Baleares regulate the possibility for all cohabiting couples, whether they are different-sex or same-sex, to adopt jointly, a matter of controversy at both the political and the constitutional level. ${ }^{37}$ Politically, much heat has been taken off the matter by the central state's granting to same-sex couples the right to marry in the same conditions and with the same rights as different-sex couples, including the right to adopt jointly.

Thus, lawmakers in eleven Autonomous Communities have given a very traditional response to cohabitation as a new social phenomenon within our civil-law tradition. The lawmaker has made cohabitation a new area of concern, a well-defined field in need of comprehensive regulation. To this end, it has responded to what it perceives to be the needs of cohabitants as a block and is satisfied to see their situation become the object of independent and comprehensive regulation. In this sense, eleven Autonomous Communities have fulfilled the role traditionally played by the central legislature.

\section{FINAL CONSIDERATIONS}

Cohabitation is a rather new social phenomenon and cohabitants feel they need responses by the legal system to the lack of protection they experience. Certainly, people who decide to forgo marriage also decide to forgo the rights and duties attached to it, but they do not decide to forgo legal protection altogether. How far they should expect protection is the matter at issue and how we handle it reveals the profile of our legal systems. Having a legal category of cohabitants created by the lawmaker and granting them rights and duties would be the traditional response of civil legal systems. In these systems the lawmaker would be left to deal with the

37 Indeed the question arises as to the extent adoption is part of the foral law of some of these Communities. 
matter. This response, however, leaves aside deeper questions, such as what rights and duties the system as it is already grants cohabitants through the general principles on which it rests and, more importantly, what cohabitants' rights and duties are already recognised in the Constitution. Of these two questions, the first one can be couched within civil-law systems without distortion, although giving it an answer means granting courts more power than they were supposed to have within these systems. The second question, on the other hand, introduces the logic of fundamental rights and, in so doing, sets two opposite logics in operation: it brings the logic of civil-law systems in direct confrontation with constitutional ways of thinking in terms of fundamental rights.

Laws on cohabitation leave unanswered the questions posed abovenamely what are the rights and duties of cohabitants embedded in the system as it is, both in its general principles and in constitutional rights. These laws do not face the question of the logic of cohabiting relationships, of the constitutional notion of the family, or of what differences between matrimony and other forms of family are justified and on which grounds. In as far 86 F.3d 916 as these questions continue to assail cohabitation, however, they will continue to be raised where the response of the laws seems insufficient and we will then have to wonder whether the absence of explicit legal regulation is due to the lawmaker's lack of foresight or to her will to leave a circumstance out of the law, thereby regulating it by implication. Moreover, conflicts between the lawmaker and the Constitutional Court are bound to arise. The ways of proceeding of civil-law systems would then have to face the logic of rights and constitutional thought.

Although recognizing the rights of both different- and same-sex cohabitants enjoys high social support in Spain, as a social phenomenon cohabitation is rather new here. Compared with other European countries, Spain has a low proportion of cohabitants (less than 3\% for all age groups between twenty and thirty-four, both for men and women, in the late nineties). ${ }^{38}$ Moreover, cohabiting couples in Spain tend to have medium to highincome levels. ${ }^{39}$ This results in the low number of cases of conflicts between cohabitants that have been known by courts. No case that I know of has, as of yet, posed a conflict between a law on cohabitation and fundamental rights, or between a law and the general principles of the system. Spanish laws on cohabitation are, let us remember, rather new. Yet in the end conflict seems inevitable and the logic of rights will have to prevail

38 Kathleen Kiernan, Cohabitation in Western Europe, 96 Population Trends, 24, 32 (1999).

39 See Constanza Tobío, Marriage, Cohabitation and the Residential Independence of Young People in Spain, 15 INT'L J.L POL'Y \& FAM. 68, 71 (2001). 
over the logic of representation. This result is a consequence of placing civil-law systems under the authority of a constitutional text. It seems to be in the nature of things that such a text should have the final say. 